\title{
Kepemimpinan Kristen di Era Bonus Demografi Pasca Sensus Penduduk Indonesia Tahun 2020
}

\author{
David Eko Setiawan \\ Sekolah Tinggi Teologi Tawangmangu \\ davidekosetiawan14217@gmail.com
}

\begin{abstract}
The results of the 2020 population census show that Indonesia is still in the era of demographic bonuses. This phenomenon can be a boon and a disaster if not appropriately addressed. Christian leadership should see this as a challenge and opportunity for the development of the present and future church. This article aims to explain Christian Leadership in the era of demographic bonuses after the 2020 Indonesian population census. While the research problem in this study is how Christian leadership in the era of demographic bonuses post-census population of Indonesia in 2020? The method used in this study is the library method. The result of this study is Christian leadership in the era of demographic bonuses post-census population of Indonesia in 2020 must be responsive to the changing times, must think about the outreach model of the younger generation more relevant and contextual, should present a holistic service model.
\end{abstract}

\section{Keywords: Christian Leadership, Demographic Bonuses, Population Census}

\begin{abstract}
Abstrak: Hasil sensus penduduk tahun 2020 menunjukkan bahwa Indonesia masih berada pada era bonus demografi. Fenomena ini dapat menjadi anugerah dan petaka jika tidak disikapi secara tepat. Kepemimpinan Kristen seharusnya memandang hal tersebut sebagai tantangan dan peluang bagi pengembangan gereja masa kini dan masa depan. Artikel ini bertujuan menjelaskan Kepemimpinan Kristen di era bonus demografi pasca sensus penduduk Indonesia tahun 2020. Sedangkan reseach problem dalam penelitian ini adalah bagaimanakah Kepemimpinan Kristen di era bonus demografi pasca sensus penduduk Indonesia tahun 2020? Metode yang digunakan dalam penelitian ini adalah metode kepustakaan. Hasil dari penelitian ini adalah Kepemimpinan Kristen di era bonus demografi pasca sensus penduduk Indonesia tahun 2020 wajib tanggap terhadap perubahan zaman, wajib memikirkan model penjangkauan generasi muda yang lebih relevan dan kontekstual, seyogyanya menghadirkan model pelayanan yang holistik.
\end{abstract}

Kata Kunci: Kepemimpinan Kristen, Bonus Demografi, Sensus Penduduk

\begin{tabular}{llll}
\hline Article History : & Received: 11-04-2021 & Revised: 20-05-2021 & Accepted: 02-06-2021 \\
\hline
\end{tabular}

\section{Pendahuluan}

Indonesia saat ini telah memasuki era bonus demografi yang ditandai dengan persentase jumlah penduduk produktif lebih besar dibandingkan dengan penduduk usia nonproduktif. ${ }^{1}$ Menurut laporan hasil sensus penduduk tahun 2020, jumlah usia

\footnotetext{
${ }^{1}$ [BPS] Badan Pusat Statistik, Berita Resmi Statistik, Bps.Go.Id, 2020, 5.
} 
produktif di Indonesia (usia 15-64 tahun) sebanyak 70,72\% dari total jumlah penduduk. ${ }^{2}$ Data ini memberikan petunjukyang nyata bahwa Indonesia masih berada pada era bonus demografi. Bonus demografi merupakan fenomena dimana struktur penduduk sangat menguntungkan dari sisi pembangunan, karena penduduk usia produktif (15-64 tahun) jumlahnya sangat besar, sementara jumlah penduduk usia muda (0-14 tahun) sudah sedikit dan jumlah penduduk usia lanjut ( 65 tahun ke atas) belum begitu banyak. ${ }^{3}$ Jika ini terjadi maka Dependency Ratio berada pada angka terendah, yaitu 50, yang berarti bahwa ada 100 orang usia produktif menanggung kurang dari 50 orang usia non produktif. ${ }^{4}$ Fenomena tersebut sangat menguntung-kan bagi Indonesia, karena modal manusia yang sangat besar ini dapat dimanfaatkan bagi pembangunan bangsa.

Namun demikian bonus demografi tidak serta merta memberikan keuntungan, karena fenomena ini juga dapat mendatangkan petaka jika tidak dikelola secara tepat dan benar. Modal manusia produktif yang melimpah jika tidak disertai dengan ketersediaan lapangan pekerjaan serta fasilitas pendukung untuk meningkatkan Sumber Daya Manusia (SDM) malah akan menghasilkan pengangguran terdidik yang hanya akan menjadi beban bagi negara. 5 Negara yang tidak siap dalam menghadapi bonus demografi akan menghadapi petaka, namun sebaliknya jika hal tersebut dipersiapkan secara matang maka akan menjadi berkat, mengingat fenomena ini hanya akan terjadi sekali saja dalam sejarah kependudukan sebuah bangsa. ${ }^{6}$ Negara-negara yang berhasil mengelola bonus demografi antara lain Korea Selatan, Jepang dan Hongkong, sedangkan yang gagal menangkap fenomena tersebut adalah India dan Pakistan. ${ }^{7}$

Bagaimanakah fenomena di atas berkorelasi dengan gereja? Salah satu unsur yang muncul dalam bonus demografi adalah hadirnya kelompok usia muda yang jumlahnya begitu besar. ${ }^{8} \mathrm{Hal}$ ini seharusnya menjadi perhatian bagi gereja, mengingat kelompok usia ini sangat penting bagi pertumbuhan gereja di masa depan. Penelitian Tenibemas menunjukkan signifikasi atas masalah ini. ${ }^{9}$ Dia menunjukkan bahwa $85 \%$ dari total

2 Ibid., 1.

${ }^{3}$ Sita Dewi, Dwi Listyowati, and Bertha Elvy Napitupulu, "Bonus Demografi Di Indonesia: Suatu Anugrah Atau Petaka," Journal of Information System, Applied, Management, Accounting and Research 2, no. 3 (2018): 19, http://journal.stmikjayakarta.ac.id/index.php/jisamar/article/view/44.

4 Ibid.

${ }^{5}$ Sri Maryati, "Dinamika Pengangguran Terdidik: Tantangan Menuju Bonus Demografi Di Indonesia," Economica 3, no. 2 (2015): 127.

6 Dewi, Listyowati, and Napitupulu, "Bonus Demografi Di Indonesia: Suatu Anugrah Atau Petaka," 17.

${ }^{7}$ Dyah Ratih Sulistyastuti, “Tantangan Indonesia Untuk Mengoptimalisasikan Bonus Demografi,” Jurnal Studi Pemuda 6, no. 1 (2018): 539.

${ }^{8}$ Berdasarkan hasil sensus penduduk Indonesia tahun 2020, tampak bahwa kelompok usia muda mendominasi total populasi penduduk Indonesia; Gen Z sebesar 29,17 juta jiwa, Gen Milenial sebesar 69,38 juta jiwa, Gen X sebesar 58,65 juta jiwa. Lihat dalam Berita Resmi Statistik No. 7/01/Th.XXIV, 21 Januari 2021.

9Purnawan Tenibemas, “Andil Kita Dalam Misi Masa Kini," Pengarah: Jurnal Teologi Kristen 1, no. 1 (2019): 23-36. 
keputusan untuk beriman kepada Yesus kali pertama diambil seseorang ketika berusia 414 tahun. ${ }^{10}$ Berdasarkan sensus penduduk tahun 2020, kelompok usia ini (sering disebut Generasi Z) menduduki jumlah yang paling besar yaitu 27,94\% atau sekitar 74,93 juta jiwa dari total jumlah penduduk Indonesia. ${ }^{11}$ Bukankah hal ini merupakan modal besar bagi perkembangan gereja di Indonesia di masa depan? Hal inilah selaras dengan penelitian Kristiono yang menunjukkan bahwa bonus demografi sebagai peluang pelayanan misi gereja di kalangan muda-mudi. ${ }^{12}$ Tetapi sayangnya, peluang besar ini tidak diikuti oleh kepemimpinan yang baik di dalam gereja sehingga malah menghasilkan kondisi yang kontra produktif. Kondisi ini tampak dari hasil penelitian Bilangan Reseach (BRC) pada tahun 2018, yang telah mengadakan survei terhadap 4.095 generasi muda Kristen (Usia 15-25 tahun) yang tersebar di 42 kota dan kabupaten di seluruh Indonesia dengan salah satu hasilnya menyatakan bahwa persentase remaja yang tidak rutin beribadah meningkat seiring kelompok usia. ${ }^{13}$ Mengapa para remaja tersebut tidak lagi tertarik untuk datang ke gereja? Hasil penelitian BRC menunjukkan 21,2 \% dari mereka menjawab karena merasa pemimpin/kepemimpinan gereja buruk. ${ }^{14}$ Ternyata kepemimpinan gereja yang buruk telah menjadi "batu sandungan " bagi mereka, maka masalah ini perlu untuk dicarikan solusi yang tepat agar kelompok usia produktif tersebut kembali tertarik ke gereja. Masalah dalam penelitian ini adalah bagaimanakah kepemimpinan Kristen di era bonus demografi pasca sensus penduduk Indonesia tahun 2020? Sedangkan Tujuan artikel ini adalah mengurai kepemimpinan Kristen yang tepat di dalam gereja pada era bonus demografi pasca sensus penduduk Indonesia tahun 2020.

\section{Metode Penelitian}

Jenis penelitian ini adalah kualitatif dengan menggunakan metode kepustakaan. Melalui metode tersebut peneliti berusaha untuk menjawab masalah penelitian yang muncul dengan mengumpulkan data-data dari berbagai referensi berupa jurnal ilmiah dan buku-buku yang relevan dengan topik yang sedang dibahas. ${ }^{15}$

Ada beberapa alasan peneliti menggunakan metode kepustakaan antara lain: Pertama, adanya sumber data yang tidak melulu didapatkan dari lapangan namun dari buku-buku, jurnal-jurnal ilmiah serta publikasi hasil penelitian lainnya. Kedua, merupakan salah satu cara untuk memahami suatu gejala-gejala baru yang belum dapat dipahami namun melalui studi kepustakaan dapat dipahami. Ketiga, data kepustakaan masih tetap handal dalam menjawab persoalan penelitian. Teknik pengumpulan data

\footnotetext{
10 Ibid., 31.

11 [BPS] Badan Pusat Statistik, Berita Resmi Statistik, 4.

12 Rahmat Kristiono, "Bonus Demografi Sebagai Peluang Pelayanan Misi Gereja Di Kalangan MudaMudi," Jurnal Teologi Berita Hidup 1, no. 2 (2019): 174-182.

13 Irawan Handi and Cemara. Putra, "Gereja Sudah Tidak Menarik Bagi Kaum Muda," Bilanganresearch.Com diakses pada tanggal 8 April 2021 pukul 18.15.

14 Ibid.

15 Kartini Kartono, Pengantar Metodologi Research Sosial (Bandung: Alumni Bandung, 1980), 78.
} 
pada penelitian ini dilakukan dengan membaca, menelaah dan mencatat kemudian disaring lalu dituangkan dalam kerangka pemikiran secara teoritis. ${ }^{16}$

Data-data di atas kemudian dianalisis mengunakan analisis isi, dimana analisis ini menitikberatkan pada penafsiran terhadap bahan-bahan tertulis berdasarkan konteksnya. Ahmad menjelaskan conten analysis sebagai usaha untuk mengupas suatu teks untuk mendapatkan gambaran dari suatu is apa adanya, tanpa campur tangan peneliti. ${ }^{17}$

Bahan-bahan tertulis yang dianalisis antara lain teks book yang berkaitan dengan topik penelitian antara karya Tomatala, Engstrom, Savitri. Selain itu juga bahan-bahan yang berasal dari jurnal ilmiah seperti karya Peramesti dan kawan-kawan, Kristiono, Heryanto, dan lain-lain. Disamping itu digunakan bahan-bahan hasil riset lembaga penelitian seperti Bilangan Reseach Center (BRC) dan Superbook Indonesia.

Penulis juga menggunakan analisis SWOT untuk mendapatkan kesimpulan yang valid dari penelitian ini. Fatimah menjelaskan analisis SWOT sebagai salah satu metode untuk mengevaluasi kekuatan (strengths), kelemahan (weaknesses), peluang (opportunities), dan ancaman (threats) yang akan menghasilkan solusi bagi sebuah permasalahan. ${ }^{18}$

\section{Hasil dan Pembahasan}

\section{Mengenal Fenomena Bonus Demografi di Indonesia}

Fenomena bonus demografi merupakan kondisi pergeseran rasio kependudukan suatu negara yang ditandai dengan meningkatnya jumlah penduduk usia produktif dibandingkan dengan usia nonproduktif. ${ }^{19}$ Pengertian lain dari fenomena ini dijelaskan oleh Savitri sebagai berikut: " Pada dasarnya bonus demografi merujuk pada percepatan pertumbuhan ekonomi sebagai dampak dari peningkatan kesehatan produksi, penurunan cepat tingkat kesuburan, dan susunan usia populasi berikutnya." 20 Jadi dapat dikatakan bahwa bonus demografi merupakan kondisi yang menguntungkan secara ekonomi akibat banyaknya usia produktif yang bekerja dan sedikitnya jumlah usia nonproduktif yang harus ditanggung. ${ }^{21}$ Jika yang menanggung lebih banyak dari pada yang ditanggung maka, berarti ada penghasilan yang lebih yang dapat dialokasikan untuk hal lain seperti

\footnotetext{
16 Moh Nazir, MetodePenelitian (Jakarta: Ghalia Indonesia, 1988), 111.

17 Jumal Ahmad, “Desain Penelitian Analisis Isi (Content Analysis),” ResearchGate, no. June (2018):

5.

18 Fatimah Fajar Nur'aini Dwi, Teknik Analisis SWOT, ed. Lestari Nurti (Yogyakarta: Anak Hebat Indonesia, 2020), 7.

${ }^{19}$ Dewi, Listyowati, and Napitupulu, “Bonus Demografi Di Indonesia: Suatu Anugrah Atau Petaka,” 19.

${ }^{20}$ Astrid Savitri, Bonus Demografi 2030 (Depok: Penerbit Genesis, 2019), 3.

${ }^{21}$ M. Subandowo, "Peradaban Dan Produktivitas Dalam Perspektif Bonus Demografi Serta Generasi Y Dan Z," SOSIOHUMANIKA: Jurnal Pendidikan Sains Sosial dan Kemanusiaan 10, no. November (2017): 195.
} 
tabungan atau investasi sehingga ini dapat memberikan keuntungan secara ekonomi. ${ }^{22}$ Secara sosial, hal tersebut juga akan berdampak pada jaminan sosial yang lebih baik, dikarenakan adanya investasi dan tabungan yang telah dipersiapkan.

Indonesia rupanya masih berada pada era bonus demografi. Hal ini tampak dari hasil sensus penduduk tahun 2020 yang menunjukkan bahwa 70,72\% penduduk Indonesia merupakan penduduk usia produktif (usia 15-64 tahun).23 Bila dilihat komposisi berdasarkan umurnya maka mayoritas penduduk Indonesia didominasi oleh tiga generasi:24 Pertama, Generasi Z dengan presentase 27,94\% (usia sekarang 8-23 tahun), Kedua, Generasi Milenial dengan presentase 25,87\% (usia sekarang 24-39 tahun). Ketiga, Generasi X dengan presentase 21,88\% (usia sekarang 40-55 tahun). Berdasarkan data tersebut tampak bahwa ke depan negara Indonesia akan didominasi oleh generasi muda yang kuat, energik dan produktif. Indonesia telah memasuki era bonus demografi pada tahun 2015 dan akan mencapai puncaknya pada tahun 2020 -2030, dan akan selesai pada pada tahun 2035. ${ }^{25}$

Tetapi, fenomena tersebut tidak serta otomatis dapat memberikan keuntungan ekonomi bagi Indonesia. Jika bonus demografi tidak disertai penyediaan lapangan pekerjaan yang luas, fasilitas kesehatan yang baik serta sarana dan prasarana pendukung untuk meningkatkan SDM maka hal itu malah berpotensi menimbulkan masalah besar bagi negara. Maka dari itu, diperlukan strategi yang jitu dalam memanfaatkan fenomena tersebut, sebab hal ini hanya akan terjadi sekali dalam sejarah kependudukan suatu bangsa. ${ }^{26}$ Telah terdapat beberapa negara yang dapat memanfaatkan peluang bonus demografi tersebut sehingga mengalami kemajuan dalam pertumbuhan ekonominya. Negara-negara tersebut antara lain Korea Selatan, Jepang dan Hongkong, tetapi juga terdapat negara-negara yang tidak mampu memanfaatkan peluang tersebut semisal India dan Pakistan. 27

\section{Tantangan dan Peluang Bonus Demografi Bagi Gereja di Indonesia}

Fenomena bonus demografi menghadirkan tantangan dan peluang bagi Indonesia. Jika hal tersebut disikapi secara bijak maka bonus demografi akan menjadi potensi yang sangat besar bagi pembangunan bangsa. Hal ini pula berlaku pada gereja, dengan meningkatnya jumlah usia produktif yang rata-rata adalah anak-anak muda seharusnya menjadi potensi bagi perkembangan gereja. Pada bagian ini akan dijelaskan tantangan dan peluang yang muncul akibat bonus demografi bagi gereja di Indonesia.

22 Dewi, Listyowati, and Napitupulu, “Bonus Demografi Di Indonesia: Suatu Anugrah Atau Petaka,”

23 [BPS] Badan Pusat Statistik, Berita Resmi Statistik, 1.

24 Ibid., 12.

19.

25 Dewi, Listyowati, and Napitupulu, “Bonus Demografi Di Indonesia: Suatu Anugrah Atau Petaka,"

${ }^{26}$ Ibid., 17.

${ }^{27}$ Sulistyastuti, “Tantangan Indonesia Untuk Mengoptimalisasikan Bonus Demografi," 539. 


\section{Tantangan Bonus Demografi}

Tantangan yang muncul akibat fenomena bonus demografi bagi gereja di Indonesia antara lain; Pertama, kesiapan gereja menjadi wadah yang relevan dalam memuridkan kelompok usia produktif. ${ }^{28}$ Salah satu faktanya yang muncul pada fenomena bonus demografi adalah banyaknya golongan orang muda yang perlu ditangani secara tepat. Jika mereka adalah kelompok usia produktif, niscaya mereka akan lebih terfokus pada pencarian jati diri dan pekerjaan yang menunjang kehidupannya. Gereja sebagai wadah pemuridan bagi jemaat muda harus mampu bersaing dengan berbagai macam "acara" yang menyibukkan kelompok generasi tersebut. Hasil survei BRC pada tahun 2018 yang menyatakan bahwa 61,8 \% remaja merasa bahwa gereja sudah tidak menarik dan tidak cocok lagi bagi mereka, seharusnya menjadi tamparan bagi gereja untuk mempersiapkan diri sebagai wadah pemuridan yang efektif. ${ }^{29}$

Kedua, gereja harus mempersiapkan pemimpin Kristen yang peka terhadap kebutuhan kelompok generasi muda. ${ }^{30}$ Jika menilik hasil sensus penduduk Indonesia tahun 2020 maka komposisi usia muda dan produktif akan menjadi mayoritas penduduk di Indonesia, karena jumlah mereka adalah $70,72 \%$ dari total jumlah populasi. ${ }^{31} \mathrm{Hal}$ ini menjadi tantangan bagi para pemipin Kristen agar semakin peka dengan kebutuhan kelompok usia tersebut. Namun demikian, merujuk hasil survei BRC pada 4.095 generasi muda Kristen (15-25 tahun) yang tersebar di 42 kota dan kabupaten di seluruh Indonesia pada tahun 2018, menunjukkan bahwa $21,2 \%$ dari para remaja yang tidak aktif ke gereja lagi merasa bahwa saat ini gereja memiliki kepemimpinan yang buruk. ${ }^{32}$ Artinya, mereka merasa bahwa kepekaan para pemimpin gereja terhadap kebutuhan mereka sangat kurang sehingga akhirnya memutuskan untuk menjauh bahkan kemudian meninggalkan gereja. ${ }^{33}$ Inilah tantangan yang harus dihadapi oleh gereja di Indonesia berkaitan dengan bonus demografi, sebab jika kelompok usia produktif tersebut mulai enggan datang atau bahkan mulai meninggalkan gereja, salah satu dampaknya buruknya adalah gereja akan kehilangan generasi produktif yang dapat dapat menjadi modal bagi pengembangan gereja di masa depan.

Ketiga, gereja harus memberikan peluang kepada generasi muda dalam pelayanan gerejawi agar relevan dengan kehidupan mereka. Berdasarkan laman superbookindonesia.com terdapat 12 (dua belas) alasan mengapa anak muda mulai $181-182$

${ }^{28}$ Kristiono, "Bonus Demografi Sebagai Peluang Pelayanan Misi Gereja Di Kalangan Muda-Mudi,"

${ }^{29}$ Irawan and Putra, “Gereja Sudah Tidak Menarik Bagi Kaum Muda," Bilanganresearch.Com.

${ }^{30}$ Herawati Barus, "Pelayanan Kaum Muda Dalam Menciptakan Generasi Yang Bersinar," SOTIRIA (Jurnal Teologi dan Pelayanan Kristiani) 2, no. 1 (2019): 37-38.

31 [BPS] Badan Pusat Statistik, Berita Resmi Statistik, 1.

32 Irawan and Putra, "Gereja Sudah Tidak Menarik Bagi Kaum Muda."

33 Ola Rongan Wilhelmus, "Berbagi Kasih Dan Berkat Allah Dengan Kaum Muda," JPAK: Jurnal Pendidikan Agama Katolik 19, no. 2 (2019): 103. 
meninggalkan gereja, dan salah satunya adalah dikarenakan peran mereka tidak dihargai di dalam pelayanan gerejawi. ${ }^{34}$ Masalah ini akan menjadi semakin pelik jika kelompok jumlah usia produktif di dalam gereja bersikap apatis terhadap gereja sehingga akan berdampak pada pertumbuhan gereja masa yang akan datang. Persoalan ini menjadi tantangan bagi gereja di Indonesia untuk menyediakan fasilitas yang dapat mengembangkan pelayanan mereka sehingga peran mereka di dalam gereja semakinsignifikan.

Keempat, gereja di Indonesia perlu memikirkan model penjangkauan yang tepat bagi tiga generasi mayoritas, yaitu Generasi Z, Milenial dan X. Meningkatnya jumlah ketiga kelompok generasi tersebut mengharuskan gereja berpikir untuk menjangkau mereka lebih banyak. Namun demikian, hal tersebut harus disertai dengan metode yang tepat. Gereja tidak boleh gagal dalam beradaptasi dengan ketiga kelompok generasi tersebut. ${ }^{35}$ Berkaitan dengan tantangan tersebut, Kristiono mengusulkan agar tidak alergi terhadap perubahan zaman yang lebih cenderung kepada teknologi Cyber malah dapat menguasainya dan menggunakannya sebagai medium penjangkauan bagi generasi muda. ${ }^{36}$

\section{Peluang Bonus Demografi}

Bonus Demografi rupanya tidak hanya menciptakan tantangan namun juga peluang bagi gereja di Indonesia. Adapun berbagai pelung tersebut adalah sebagai berikut: Pertama, gereja di Indonesia memiliki potensi jemaat yang produktif. Dengan meningkatnya jumlah usia produktif maka terdapat peluang gereja juga akan "dihuni" oleh mereka. Jika penjangkaun kepada kelompok usia ini dapat berhasil dan pengembangan SDM mereka di dalam gereja dapat terlaksana, maka kelompok usia tersebut menjadi kekuatan bagi pertumbuhan gereja masa depan.

Kedua, gereja di Indonesia akan semakin kreatif dalam mengembangkan pelayanannya. Hadirnya tiga kelompok usia produktif yaitu Generasi Z, Milenial dan X, pastinya akan mendorong gereja untuk mengembangkan pelayanan yang lebih kreatif dan menarik. Kehadiran mereka memberikan peluang untuk menjawab kegundahan anak muda yang merasa bosan dan tidak relevannya pelayanan gereja dengan kehidupan mereka. ${ }^{37}$

Ketiga, terbukanya peluang untuk mencetak pemimpin muda Kristen yang produktif, energik dan berkualitas. Kritik para remaja Kristen yang enggan datang ke gereja lagi akibat kepemimpinan Kristen yang buruk seharusnya menjadi pemicu bagi

\footnotetext{
34 "Fakta Yang Menyebabkan Anak Muda Meninggalkan Gereja. Apakah Gereja Mau Berdiam Diri Saja?," Superbookindonesia.Com.

35 Ibid.

${ }^{36}$ Kristiono, "Bonus Demografi Sebagai Peluang Pelayanan Misi Gereja Di Kalangan Muda-Mudi," 181.

37 "Fakta Yang Menyebabkan Anak Muda Meninggalkan Gereja. Apakah Gereja Mau Berdiam Diri Saja?"
} 
gereja masa kini untuk dapat mempersiapkan pemimpin yang berkualitas dan peka terhadap perubahan zaman. ${ }^{38} \mathrm{Hal}$ inilah yang menjadi salah satu usulan dari dari BRC dalam mengatasi ketidaktertarikan anak muda terhadap gereja. Dengan meningkatnya jumlah generasi muda akibat fenomena bonus demografi maka gereja Indonesia memiliki peluang untuk mempersiapkan anak-anak muda menjadi the next leader yang akan membawa kemajuan bagi gereja. Hal ini selaras dengan penjelasan Heryanto bahwa para pemimpin gereja tidak boleh memandang sebelah mata terhadap potensi generasi muda di dalam gereja, mereka perlu untuk dibina sehingga akan menjadi pemimpin Kristen masa depan yang dewasa secara rohani dan berkarakter Kristus. ${ }^{39}$

\section{Hakikat Kepemimpinan Kristen}

Menurut Kamus Besar Bahasa Indonesia , kepemimpinan dapat diartikan sebagai perihal pemimpin; cara memimpin. ${ }^{40}$ Kepemimpinan juga dapat diartikan sebagai kegiatan memengaruhi orang-orang untuk mencapai tujuan organisasi. ${ }^{41}$ Jadi pada dasarnya kepemimpinan berbicara tentang bagaimana cara atau usaha pemimpin dalam mengarahkan orang-orang yang sedang dipimpinnya agar mereka secara bersama-sama dapat mencapai tujuan-tujuan utama dari sebuah organisasi. Lalu bagaimanakah dengan Kepemimpinan Kristen. Pada bagian ini akan dijelaskan tentang bagaimankah hakikat Kepemimpinan Kristen itu.

\section{Pengertian Kepemimpinan Kristen}

Siahaya berpendapat bahwa pada dasarnya Kepemimpinan Kristen memiliki prinsip yang sama dengan kepemimpinan secara umum. ${ }^{42}$ Namun demikian, Kepemimpinan Kristen tetap memiliki perbedaan pada landasan kepemimpinannya yaitu Alkitab serta sifatnya yang teosentris.43 Sedangkan Engstrom menjelaskan Kepemimpinan Kristen merupakan kepemimpinan yang dimotivasi oleh kasih dan berorientasikan kepada pelayanan. ${ }^{44}$ Sedangkan Tomatala menjelaskan Kepemimpinan

\footnotetext{
38 Irawan and Putra, "Gereja Sudah Tidak Menarik Bagi Kaum Muda."

39 Heryanto, "Peran Pemimpin Gereja Dalam Kepemimpinan Pelayanan Kaum Muda Masa Kini," HARVESTER: Jurnal Teologi dan Kepemimpinan Kristen 5, no. 1 (2020): 71.

40 Kemendikbud Badan Pengembangan dan Pembinaan Bahasa, "Kamus Besar Bahasa Indonesia Daring," last modified 2016, https://kbbi.kemdikbud.go.id/entri/kepemimpinan diakses pada tanggal 9 April 2021.

41 Ni Putu Depi Yulia Peramesti and Dedi Kusmana, "Kepemimpinan Ideal Pada Era Generasi Milenial," TRANSFORMASI: Jurnal Manajemen Pemerintahan 10, no. 1 (2018): 74.

42 Johannis Siahaya, "Kepemimpinan Kristen Dalam Pluralitas Indonesia," Jurnal Teruna Bhakti 1, no. 1 (2019): 6.

43 Ibid.

44 Ted Engstrom and Edward Dayton, Seni Manajemen Bagi Pemimpin Kristen (Bandung: Yayasan Kalam Hidup, 1998), 20.
} 
Kristen merupakan kepemimpinan yang menekankan aspek melayani Allah, gereja dan penginjilan dunia. 45

Berdasarkan berbagai penjelasan di atas maka Kepemimpinan Kristen dapat didefinisikan sebagai kepemimpinan yang menekankan pelayanan serta dimotivasi oleh kasih yang berlandaskan Alkitab dan teosentris untuk melayani Allah, gereja dan penginjilan dunia.

\section{Yesus Kristus: Model Kepemimpinan Kristen yang Sempurna}

Kepemimpinan Kristen memiliki model yang jelas yaitu kepemimpinan Yesus Kristus. Mengapa demikian? Penulis perpendapat karena Yesus Kristus adalah sosok yang paling ideal di dalam Alkitab. Dia adalah Allah yang menjelma sebagai manusia (Yoh. 1:114) serta memberikan keteladan hidup dan kepemimpinan yang sempurna. ${ }^{46}$ Lalu bagaimanakah model kepemimpinan Yesus Kristus itu? Panjaitan menjelaskan model kepemimpinan tersebut sebagai berikut; ${ }^{47}$ Pertama, Kepemimpinan Yesus mematahkan belenggu kebencian dengan cara menolak untuk membenci. Jika model ini diberlakukan maka akan tercipta perdamaian dalam hidup manusia, khususnya dalam kepemimpinan. Seorang pemimpin harus mampu mematahkan lingkaran kekerasan dengan lebih dahulu mengatasi kebencian yang ada di dalam dirinya sendiri.

Kedua, Kepemimpinan Yesus menekankan pelayanan yang penuh penghargaan atas martabat para pengikut-Nya. Model kepemimpinan ini diwujudkan dalam kewibawaan-Nya dalam memimpin yang tumbuh bukan karena sikap otoriter namun dari kerendahan hati-Nya.

Ketiga, Kepemimpinan Yesus menekankan rasa kesetiakawanan yang inklusif tanpa memandang bulu berdasarakan nilai kemanusiaan. Model kepemimpinan ini menciptakan sikap adil tanpa membeda-bedakan kepada siapapun.

Keempat, Kepemimpinan Yesus selalu dekat kepada mereka yang termarginalkan. Model kepemimpinan ini menciptakan sikap bela rasa kepada mereka yang tertindas sebagai wujud dari Pemerintahan Allah.

Jika diamati model Kepemimpinan Yesus tersebut maka dapat diringkaskan bahwa Kepemimpinan Yesus pada dasarnya adalah kepemimpinan yang menekankan keteladanan hidup, yang berpusat dari hati nurani dan bermotifkan pelayanan kasih kepada Allah dan sesama serta ketersediaan untuk menghamba. Model ini harus menjadi acuan bagi setiap pemimpin Kristen dalam kepemimpinannya.

${ }^{45}$ Yakob Tomatala, Kepemimpinan Yang Dinamis (Jakarta: YT Leadership Foundation, 1997), 43.

${ }^{46}$ Firman Panjaitan, "Kepemimpinan Yesus Kristus Sebagai Model Dasar Kepemimpinan Kristen Berdasarkan Matius 20:20-28," KINAA: Jurnal Kepemimpinan Kristen dan Pemberdayaan Jemaat 1, no. 2 (2020): 93.

${ }^{47}$ Ibid., 103-108. 


\section{Karakteristik Kepemimpinan Kristen}

Karakteristik didefinisikan oleh Kamus Besar Bahasa Indonesia sebagai sifat khas dengan perwatakan tertentu. ${ }^{48}$ Sedangkan Oxford Learner's Dictionaries menjlaskan kata characteristic sebagai "a typical feature or quality that something/somebody has" Jadi, berbicara tentang karakteristik Kepemimpinan Kristen berarti berkaitan dengan ciri khas yang tampak dalam watak atau sifat pemimpin Kristen dalam memimpin. Pappalan menjelaskan beberapa karakteristik yang dapat menjadi penanda bagi Kepemimpinan Kristen antara lain: Kepemimpinan yang rendah hati, rela berkorban, bukan sekedar konseptor namun juga pelaku, berani dan penurut, jujur. 49

Selain karakteristik di atas, Kepemimpinan Kristen di era bonus demografi seharusnya memiliki beberapa karakter khusus. Mengingat pasca sensus penduduk Indonesia tahun 2020, fenomena tersebut telah menghadirkan tiga kelompok generasi yang menjadi mayoritas penduduk Indonesia masa kini, yaitu Generasi Z, Melienial dan X. Jika merujuk pada penelitian Paramesti dan Kusmana pada tahun 2018, rupanya kepemimpinan yang idel bagi generasi Milenial (sebagai salah satu kelompok usia bonus demografi di Indonesia) adalah sebagai berikut: 50 Pertama, Digital Mindset. Seiring perkembangan dunia digital maka segala hal saat ini selalu terkait dengan teknologi digital. Penggunaan perangkat digital telah menjadi sebuah kebutuhan yang tak terhindarkan dalam menyelesaian pekerjaan. Seorang pemimpin masa kini yang tidak memiliki Digital Mindset akan dianggap kuno dan tidak mampu beradaptasi dengan perubahan zaman.

Kedua, Observer dan Active Listener. Karakter ini ditandai dengan kemampuan seorang pemimpin untuk dalam memperhatikan dan menjadi pendengar aktif. Generasi Milenial dan media sosial bagaikan dua sisi mata uang yang tidak terpisahkan. "Kecanduan" pada media sosial telah membuat generasi tersebut ingin terus untuk diperhatikan. Mereka akan sangat termotivasi bila didengarkan dan dihargai serta diberi kesempatan untuk mengekpresikan ide-idenya.

Ketiga, Agile. Karakter ini ditandai dengan kecerdasan dalam melihat peluang, cepat beradaptasi dan lincah dalam memfasilitasi perubahan. Pemimpin dengan karakter Agile cenderung open minded dan terbuka terhadap saran, ide, kritik dan pandangan orang lain.

Keempat, Inclusive. Pemimpin yang berkarakter Inclusive ditandai dengan kemampuan menghargai perbedaan pandangan serta menggunakannya untuk mencapai tujuan organisasi. Generasi Milenial adalah kelompok usia produktif yang intim dengan

\footnotetext{
48 Kemendikbud Badan Pengembangan dan Pembinaan Bahasa, "Kamus Besar Bahasa Indonesia Daring" diakses pada 9 April 2021.

${ }^{49}$ Abialtar Pappalan, "Aspek-Aspek Penting Dari Kepemimpinan Dalam Aspek Spiritual Dan Sosial," Kinaa: Jurnal Kepemimpinan Kristen dan Pemberdayaan Jemaat 1, no. 2 (2020): 80-88.

50 Peramesti and Kusmana, "Kepemimpinan Ideal Pada Era Generasi Milenial," 79-80.
} 
media digital, sehingga mereka mendapatkan banyak sumber informasi bagi ide-ide kreatif mereka. Adakalanya hal ini dapat menimbulkan perbedaan-perbedaan sudut pandang, namun kepemimpinan milenial yang idel dapat mengelolanya demi pencapaian tujuan bersama.

Kelima, Brave to be Different. Kerakter ini ditunjukkan dengan keberanian untuk mengambil langkah atau keputusan penting dalam pencapaian cita-cita. Meskipun kadang harus bertentangan dengan tradisi organisasi, namun jika untuk menghambat pencapaian cita-cita yang lebih baik, maka pemimpin berkarater Brave to be Different tidak akan mundur selangkah pun.

Keenam, Unbeatable. Karakter kepemimpinan milenial tersebut ditandai dengan mindset yang pantang menyerah. Terlebih ketiga berhadapan dengan Generasi Milenial yang terkenal malas, manja dan ingin menang sendiri. Hambatan yang menghadang pemimpin dengan karakter Unbeatable akan selalu tabah menghadapi berbagai tantangan dalam kepemimpinannya.

\section{Kepemimpinan Kristen dan Bonus Demografi: Sebuah Usulan Konkrit}

Kepemimpinan Kristen di Indonesia mas kini sedang diperhadapkan dengan fenomena bonus demografi. Pasca sensus penduduk Indonesia tahun 2020, tampak bahwa komposisi demografi penduduk negara ini telah mengalami pergeseran. Mayoritas penduduk adalah generasi usia produktif dengan presentasi 70, 72\% dari total jumlah populasi penduduk Indonesia. ${ }^{51}$ Artinya, Kepemimpinan Kristen akan sering diperhadapkan dengan tiga kelompok generasi usia produktif, baik di gereja maupun di luar gereja. Mengingat hal tersebut maka penulis mengusulkan tiga langkah konkrit bagai para pemimpin Kristen dalam menyikapi fenomena tersebut.

\section{Langkah Pertama: Para Pemimpin Kristen Wajib Tanggap Terhadap Perubahan Zaman}

Perubahan zaman tidak dapat dipungkiri oleh setiap orang, terlebih pada para pemimpin Kristen. Pergeseran budaya akibat dominasi penduduk usia produktif dengan budaya digitalnya, akan semakin jelas ke depan. Hal ini harus segera diantisipasi oleh para pemimpin Kristen dalam kepemimpinannya. Perubahan dari segala sesuatu yang "rumit" menjadi lebih praktis dan cepat akan menjadi tantangan tersendiri bagi setiap pemimpin Kristen. Para pemimpin akan didorong memiliki digital mindset sebagai wujud kemampuannya untuk beradaptasi dengan perubahan zaman.

Bagaimanakah kesanggupan para pemimpin Kristen dalam menghadapi perubahan zaman yang begitu cepat ini? Jika dilihat dari hasil survei yang dilakukan oleh BRC tentang pelayanan dan dinamika gereja selama masa pandemi Covid-19, tampak

51 [BPS] Badan Pusat Statistik, Berita Resmi Statistik, 1. 
47,2\% digital maindset para pemimpin Kristen cenderung reactive. ${ }^{52}$ Saat pandemi Covid19 , gereja menghadapi perubahan yang begitu cepat khususnya pada kesiapan dalam pelayanan gerejawi yang berbasis digital. Rupanya, berdasarkan survei tersebut ada banyak pemimpin Kristen yang masih gagap dalam menghadapinya sehingga cen derung reactive. Orang yang memiliki sikap reaktif memiliki ciri-ciri sebagai berikut: Sangat mudah tersinggung, cenderung menyalahkan orang lain dan situasi, cepat marah lalu menyesal, selalu merasa menjadi korban atas situasi yang menimpa dirinya, berubah hanya kalau perlu saja. ${ }^{53}$ Berdasarkan hal ini, jelas masih banyak pemimpin Kristen yang belum siap menghadapi perubahan zaman dalam kepemimpinannya. Maka dari itu, mulai saat ini, wajiblah bagi mereka untuk tanggap terhadap perubahan tersebut.

\section{Langkah Kedua: Kepemimpinan Kristen Wajib Memikirkan Model Penjangkauan Generasi Muda yang lebih Relevan dan Kontekstual}

Bonus demografi pasca sensus penduduk Indonesia tahun 2020 menjadi peluang bagi misi penjangkauan terhadap generasi produktif atau dikenal sebagai generasi muda. ${ }^{54} \mathrm{Hal}$ ini seharusnya mendorong Kepemimpinan Kristen untuk memikirkan model penjangkauan yang lebih relevan dan kontekstual. Bila merujuk pada hasil survei BRC pada tahun 2018 kepada kurang lebih 4.095 generasi muda di Indonesia menunjukkan bahwa $61,8 \%$ partisipan merasa bahwa sudah tidak menarik dan tidak cocok bagi mereka. ${ }^{55}$ Situasi ini sangat menyedihkan, mengingat dengan keadaan tersebut orang muda akan lebih sulit untuk dijangkau. Hal ini harus dipikirkan secara serius oleh para pemimpin Kristen agar mereka dapat tertarik kepada Injil yang diberitakan oleh gereja (baca: orang percaya). Injil tersebut harus disampaikan secara kontekstual agar relevan dengan pendengarnya. Setiawan menjelaskan bahwa melalui metode kontekstualisasi berita injil dapat dibalut dengan kebudayaan yang sesuai dengan konteks pendengarnya. ${ }^{56}$

Berkaitan dengan hal di atas maka perlu digali konteks kebudayaan dari ketiga generasi yang dominan pasca sensus penduduk di Indonesia tahun 2020. Generasi tersebut adalah Generasi Z, Milenial dan X. Sebagai bahan pertimbangan bagi para pemimpin Kristen, di bawah ini disajikan karakteristik ketiga generasi berdasarkan penelitian Bencsik dan Machova.

\footnotetext{
52 Bilangan Reseach Center, Seminar On Line: Hasil Temuan Survei Nasional Tentang Pelayanan Dan Dinamika Gereja Selama Pandemi Covid-19 (Jakarta, 2020), 58. April 2021.

53 Studiilmu, “Apa Itu Proaktif Dan Reaktif?," https://www.studilmu.com/ diakses pada tanggal 11

${ }^{54}$ Kristiono, "Bonus Demografi Sebagai Peluang Pelayanan Misi Gereja Di Kalangan Muda-Mudi," 181.

55 Irawan and Putra, “Gereja Sudah Tidak Menarik Bagi Kaum Muda” diakses pada 11 April 2021.

56 David Eko Setiawan, "Menjembatani Injil Dan Budaya Dalam Misi Melalui Metode Kontektualisasi," Fidei: Jurnal Teologi Sistematika dan Praktika 3, no. 2 (2020): 177.
} 
Tabel. 1

Karakteristik Prilaku Generasi dari kelompok -kelompok usia yang berbeda ${ }^{57}$

\begin{tabular}{|c|c|c|c|}
\hline Faktor & Generasi X & Generasi Milenial & Generasi Z \\
\hline Cara Pandang & $\begin{array}{l}\text { Berpusat pada diri } \\
\text { sendiri dan jangka } \\
\text { menengah }\end{array}$ & Egois, jangka pendek & $\begin{array}{l}\text { Tidak ada rasa } \\
\text { komitmen, senang } \\
\text { dengan apa yang Anda } \\
\text { miliki dan hidup untuk } \\
\text { saat ini }\end{array}$ \\
\hline Relasi & $\begin{array}{l}\text { Pribadi dan jejaringan } \\
\text { virtual }\end{array}$ & Viritual dan jejaring & Viritual dan dangkal \\
\hline Tujuan & $\begin{array}{l}\text { Multi-environment, } \\
\text { posisi yang aman }\end{array}$ & $\begin{array}{l}\text { Persaingan untuk posisi } \\
\text { pemimpin }\end{array}$ & Hidup untuk saat ini \\
\hline Realisasi diri & Promosi cepat & Segera & $\begin{array}{l}\text { Mempertanyakan dulu } \\
\text { apa kebutuhannya }\end{array}$ \\
\hline IT & $\begin{array}{l}\text { Penggunakannya dengan } \\
\text { penuh keyakinan }\end{array}$ & $\begin{array}{l}\text { Bagian dari kehidupan } \\
\text { sehari-hari }\end{array}$ & Spontan/otomatis \\
\hline Nilai-nilai & $\begin{array}{l}\text { Kerja keras, keterbukaan, } \\
\text { penghormatan terhadap } \\
\text { keragaman, } \\
\text { keingintahuan, } \\
\text { kepraktisan }\end{array}$ & $\begin{array}{l}\text { Fleksibilitas, mobilitas, } \\
\text { pengetahuan luas tapi } \\
\text { dangkal, orientasi } \\
\text { keberhasilan, } \\
\text { kreativitas, kebebasan } \\
\text { informasi menjadi } \\
\text { prioritas }\end{array}$ & $\begin{array}{l}\text { Hidup untuk saat ini, } \\
\text { reaksi cepat terhadap } \\
\text { segala sesuatu, } \\
\text { inisiator, berani, akses } \\
\text { informasi cepat dan } \\
\text { pencarian konten }\end{array}$ \\
\hline
\end{tabular}

Berdasarkan hasil riset di atas tampak bahwa setiap generasi memiliki karakteristik yang berbeda-beda. Hal ini juga akan berpengaruh pada budaya yang diwujudkan dalam lifestyle mereka. Dengan memahami karakteristik ketiga kelompok usia produktif tersebut diharapkan para pemimpin Kristen dapat menyusun model misi penjangkaun yang kontekstual dan relevan dengan mereka. Adapun usulan model penjangkuan yang kontekstual dan relevan dengan mereka adalah model penjangkauan yang berbasis IT. Hal ini didasarkan atas kesamaan karakteristik dari ketiga generasi di atas, yaitu memiliki kedekatan dengan dunia IT. Disamping itu dapat juga diberdayakan berbagai platform media sosial sebagai medium relasi dengan generasi tersebut, mengingat mereka rupanya merupakan generasi yang lebih nyaman dengan model relasi secara viritual.

${ }^{57}$ A Bencsik and R. Machova, "Knowledge Sharing Problems from the Viewpoint of Intergeneration Management. In ICMLG2016," in 4th International Conferenceon Management, Leadership and Governance (ICMLG2016, 2016), 42. 


\section{Langkah Ketika: Kepemimpinan Kristen Seyogyanya Menghadirkan Model Pelayanan yang Holistik}

Bonus demografi selain menjadi peluang namun juga menjadi tantangan. Tantangan terbesar pada era ini adalah ketersediaan lapangan pekerjaan yang luas dan peningkatan SDM. Menghadapi tantangan tersebut, para pemimpin Kristen seyogyanya mulai membangun pelayanan yang holistik. Pelayan holistik yang dimaksud di sini adalah pelayanan yang menyentuh kebutuhan individual maupun sosial, baik kebutuhan fisik, psikis dan spiritualnya. ${ }^{58} \mathrm{Hal}$ ini selaras dengan penjelasan Barus bahwa pelayanan kepada generasi muda merupakan sebuah misi yang holistik. ${ }^{59}$

Kepemimpinan Kristen harus terlibat aktif dalam peningkatan SDM warga jemaat muda dengan memberikan pelatian-pelatihan, juga menunjang perbaikan gizi dan kesehatan mereka dengan mengadakan Pekan Sehat bagi mereka, dan atau kegiatankegiatan lain yang berorientasi bukan saja pada pelayanan rohani, namun juga pelayanan lain yang dapat meningkatkan kualitas hidup warga jemaat.

Para pemimpin Kristen juga harus memulai membentuk network dengan pengusaha-pengusaha Kristen dan juga para penggiat usaha, agar dapat terbuka peluang bagi penyediaan lapangan kerja baru bagi kelompok usia produktif. Jika usaha ini dapat dilakukan maka gereja akan memiliki daya tarik tersendiri bagi generasi muda. Mengingat, mereka adalah generasi yang lebih cenderung melihat hasil dan bukan sekedar teori di atas mimbar saja.

\section{Kesimpulan}

Fenomena bonus demografi pasca sensus penduduk Indonesia tahun 2020, seyogyanya "membangunkan" para pemimpin Kristen masa kini bahwa telah terjadi pergeseran jumlah populasi penduduk di Indonesia. Fenomena tersebut dapat menjadi anugerah namun juga dapat menjadi petaka, bila para pemimpin Kristen tidak mempersiapkan diri dalam kepemimpinannya. Kepemimpinan Kristen di era bonus demografi harus mampu membaca peluang dan tantangan yang ada sehingga mampu menjawab perubahan-perubahan yang terjadi. Dengan meningkatnya jumlah populasi generasi muda yang produktif, maka para pemimpin Kristen perlu memiliki karakter Digital Mindset, Observer dan Active Listener, Agile, Inclusive, Brave to be Different, Unbeatable. Karakteristik tersebut penting karena selaras dengan konteks kebutuhan generasi X (milenila), Y dan Z. Disamping itu kepemimpinan Kristen perlu memiliki model kepemimpinan Yesus.

\footnotetext{
58 Reinhard Jeffray Berhitu, "Peran Gembala Jemaat Terhadap Pengembangan Pelayanan Holistik Di Gereja Kemah Injil Indonesia Jemaat Yegar Sahaduta Jayapura," Jurnal Jaffray 12, no. 2 (2014): 275.

${ }^{59}$ Barus, "Pelayanan Kaum Muda Dalam Menciptakan Generasi Yang Bersinar," 38.
} 
Selanjutnya, penulis telah mengusulkan mengusulkan tiga langkah konkrit bagai para pemimpin Kristen dalam menyikapi fenomena bonus demografi pasca sensus penduduk Indonesia tahun 2020 yaitu; Pertama, para pemimpin Kristen wajib tanggap terhadap perubahan zaman. Kedua, kepemimpinan Kristen wajib memikirkan model penjangkauan yang lebih relevan dan kontekstual. Ketiga, kepemimpinan Kristen seyogyanya menghadirkan model pelayanan yang holistik.

\section{Referensi}

[BPS] Badan Pusat Statistik. Berita Resmi Statistik. Bps.Go.Id, 2020.

Barus, Herawati. "Pelayanan Kaum Muda Dalam Menciptakan Generasi Yang Bersinar." SOTIRIA (Jurnal Teologi dan Pelayanan Kristiani) 2, no. 1 (2019): 30-38.

Bencsik, A, and R. Machova. "Knowledge Sharing Problems from the Viewpoint of Intergeneration Management. In ICMLG2016." In 4th International Conferenceon Management, Leadership and Governance. ICMLG2016, 2016.

Berhitu, Reinhard Jeffray. "Peran Gembala Jemaat Terhadap Pengembangan Pelayanan Holistik Di Gereja Kemah Injil Indonesia Jemaat Yegar Sahaduta Jayapura." Jurnal Jaffray 12, no. 2 (2014): 273.

Bilangan Reseach Center. Seminar On Line: Hasil Temuan Survei Nasional Tentang Pelayanan Dan Dinamika Gereja Selama Pandemi Covid-19. Jakarta, 2020.

Dewi, Sita, Dwi Listyowati, and Bertha Elvy Napitupulu. "Bonus Demografi Di Indonesia: Suatu Anugrah Atau Petaka." Journal of Information System, Applied, Management, Accounting and Research 2, no. 3 (2018): 17-23. http://journal.stmikjayakarta.ac.id/index.php/jisamar/article/view/44.

Engstrom, Ted, and Edward Dayton. Seni Manajemen Bagi Pemimpin Kristen. Bandung: Yayasan Kalam Hidup, 1998.

Fajar Nur'aini Dwi, Fatimah. Teknik Analisis SWOT. Edited by Lestari Nurti. Yogyakarta: Anak Hebat Indonesia, 2020.

Handi, Irawan, and Cemara. Putra. "Gereja Sudah Tidak Menarik Bagi Kaum Muda." Bilanganresearch.Com.

Heryanto. "Peran Pemimpin Gereja Dalam Kepemimpinan Pelayanan Kaum Muda Masa Kini." HARVESTER: Jurnal Teologi dan Kepemimpinan Kristen 5, no. 1 (2020): 59-72.

Irawan, and Cemara . Putra. "Gereja Sudah Tidak Menarik Bagi Kaum Muda." Bilanganresearch.Com.

Jumal Ahmad. "Desain Penelitian Analisis Isi (Content Analysis).” ResearchGate, no. June (2018): 1-20. https://www.researchgate.net/publication/325965331.

Kartono, Kartini. Pengantar Metodologi Research Sosial. Bandung: Alumni Bandung, 1980.

Kemendikbud Badan Pengembangan dan Pembinaan Bahasa. "Kamus Besar Bahasa Indonesia Daring." Last modified 2016. https://kbbi.kemdikbud.go.id/entri/pandemi.

Kristiono, Rahmat. "Bonus Demografi Sebagai Peluang Pelayanan Misi Gereja Di Kalangan Muda-Mudi.” Jurnal Teologi Berita Hidup 1, no. 2 (2019): 174-182.

Maryati, Sri. "Dinamika Pengangguran Terdidik: Tantangan Menuju Bonus Demografi Di Indonesia." Economica 3, no. 2 (2015): 124-136.

Nazir, Moh. MetodePenelitian. Jakarta: Ghalia Indonesia, 1988.

Panjaitan, Firman. "Kepemimpinan Yesus Kristus Sebagai Model Dasar Kepemimpinan Kristen Berdasarkan Matius 20:20-28." KINAA: Jurnal Kepemimpinan Kristen dan 
Pemberdayaan Jemaat 1, no. 2 (2020): 91-110.

Pappalan, Abialtar. "Aspek-Aspek Penting Dari Kepemimpinan Dalam Aspek Spiritual

Dan Sosial." Kinaa: Jurnal Kepemimpinan Kristen dan Pemberdayaan Jemaat 1, no. 2 (2020): 78-90.

Peramesti, Ni Putu Depi Yulia, and Dedi Kusmana. "Kepemimpinan Ideal Pada Era Generasi Milenial." TRANSFORMASI: Jurnal Manajemen Pemerintahan 10, no. 1 (2018): 73-84.

Savitri, Astrid. Bonus Demografi 2030. Depok: Penerbit Genesis, 2019.

Setiawan, David Eko. "Menjembatani Injil Dan Budaya Dalam Misi Melalui Metode

Kontektualisasi." Fidei: Jurnal Teologi Sistematika dan Praktika 3, no. 2 (2020): 160180.

Siahaya, Johannis. "Kepemimpinan Kristen Dalam Pluralitas Indonesia." Jurnal Teruna Bhakti 1, no. 1 (2019): 1.

Studiilmu. "Apa Itu Proaktif Dan Reaktif?" Https://Www.Studilmu.Com/.

Subandowo, M. "Peradaban Dan Produktivitas Dalam Perspektif Bonus Demografi Serta Generasi Y Dan Z." SOSIOHUMANIKA: Jurnal Pendidikan Sains Sosial dan Kemanusiaan 10, no. November (2017): 191-208.

Sulistyastuti, Dyah Ratih. "Tantangan Indonesia Untuk Mengoptimalisasikan Bonus Demografi." Jurnal Studi Pemuda 6, no. 1 (2018): 538.

Tenibemas, Purnawan. “Andil Kita Dalam Misi Masa Kini." Pengarah: Jurnal Teologi Kristen 1, no. 1 (2019): 23-36.

Tomatala, Yakob. Kepemimpinan Yang Dinamis. Jakarta: YT Leadership Foundation, 1997.

Wilhelmus, Ola Rongan. "Berbagi Kasih Dan Berkat Allah Dengan Kaum Muda." JPAK: Jurnal Pendidikan Agama Katolik 19, no. 2 (2019): 100-112.

"Fakta Yang Menyebabkan Anak Muda Meninggalkan Gereja. Apakah Gereja Mau Berdiam Diri Saja?" Superbookindonesia.Com. 